\title{
Bawinanga and CDEP: The vibrant life, and near death, of a major Aboriginal corporation in Arnhem Land
}

\author{
Jon Altman
}

\section{Introduction}

In this chapter, I examine the Bawinanga Aboriginal Corporation (also referred to as Bawinanga or BAC) located at Maningrida in Arnhem Land. Bawinanga is an Aboriginal corporation and for over 20 years it was also a Community Development Employment Projects (CDEP) organisation. It was established in 1979 and, during the first decade of the 21 st century, it became one of the largest and most financially successful Indigenous corporations in Australia. For a number of years between 2004-05 and 2010-11, Bawinanga was ranked as the second-largest Indigenous corporation in Australia by the Office of the Registrar of Indigenous Corporations.

Bawinanga succeeded in remote and difficult circumstances largely devoid of market opportunity where others, including the Australian colonial state from 1957, have failed. Its only serious competitor in the Maningrida region is the Maningrida Progress Association, a community-owned organisation that focuses on retail trade in the 
township of Maningrida. Much of Bawinanga's success can be linked historically to its productive deployment and reconfiguring of CDEP funding support from the Australian government.

I focus here on the relationship between CDEP and Bawinanga, as their life cycles are closely related; Bawinanga was established as a small community-based outstation resource agency in 1979 two years after CDEP began. Both were new and innovative institutions of what Tim Rowse (2002) has termed 'the Indigenous sector'.

Despite an early application for CDEP funding in 1980, it was not until 1989 that access to CDEP was provided to Bawinanga to be delivered initially to 'unemployed' (in a formal Western labour market sense) residents of the outstations in its 10,000-square-kilometre-sphere of geographic influence.

From then, Bawinanga gradually changed into a successful regional development corporation. Its growth, highly contingent on the entrepreneurial zeal and political acumen of its senior management, was largely underwritten by access to CDEP.

From 1989 to 2009 Bawinanga grew quickly. This period can be roughly divided by the period between 1989 and 1996, when CDEP was incrementally integrated into Bawinanga's operations, and the time after 1996 when the corporation became increasingly involved in small business development and the delivery of diverse services with associated normalisation and developmental undercurrents.

From 2009 the corporation's fortunes declined, reflecting in some measure significant changes to CDEP. These changes had been signalled for some time, at least since the transfer of the program on 1 July 2004 from the Aboriginal and Torres Strait Islander Commission (ATSIC) to the Department of Employment and Workplace Relations (DEWR) when the former was effectively abolished. Much of this policy history has been told in early chapters of this monograph (see also Sanders 2012; and Appendix 1, this volume). A key element of this administrative change saw CDEP shift from operating as a grant-in-aid program to being defined as a contracted service. This change reflected the new public management or managerialism infusing Indigenous policy at the time (Sullivan 2011: 67-83). 
From 2005 CDEP was slowly dismantled as the effective means to underwrite community development, and abolished a decade later. This 'reform' coincided with a rapid decline in Bawinanga's fortunes that was also greatly influenced by changes in its management and operating style and enhanced instability in political relations with the Australian Government.

In October 2012 Bawinanga went into special administration, what I term 'near death', owing to short-term insolvency, a situation from which it has recovered from July 2014, much reduced and deeply indebted. During the period of special administration, CDEP was replaced by the Remote Jobs and Communities Program (RJCP) and Bawinanga was selected as the regional provider despite its financial troubles.

In this chapter, I provide an account of the consequences of the demise of CDEP for Bawinanga, its members and the regional population more generally. My focus is on the multiple somewhat contradictory roles of Bawinanga as an economic development agency (Altman \& Johnson 2000) as well as a political institution (Rowse 2001a) and community development institution (Martin 2001). This is counter to an increasingly dominant narrative that irrationally emphasises CDEP as a labour market program only and hence measures success or failure in terms of 'real' jobs - a euphemism for forms of regular employment that are very limited in number in the Maningrida region. This shift is linked to a wider discourse that seeks to blame the policy of selfdetermination and ATSIC for disappointing outcomes in Indigenous affairs generally. This same discourse proposes to Close the Gap through mainstreaming or normalisation, even in remote Arnhem Land.

The CDEP reform agenda has been deeply influenced by a discourse brought to national prominence by Noel Pearson around 'welfare poison', the need for Aboriginal engagement in 'real' jobs in the 'real' economy, and the overarching need for Aboriginal individuals to be 'responsibilised' (Kowal 2012). The use of the term 'real' is a trope that not only requires imagination in the unreal circumstances of remote Indigenous Australia, but is also contingent on a certain settler belief and value system. In this increasingly dominant narrative, CDEP has been depicted as a form of welfare and as a form of exceptionalism that has operated as a barrier to the engagement of Aboriginal people with the labour market. 
In this chapter, I begin by outlining my entanglements as a policy anthropologist with Bawinanga. This is mainly because I use a particular voice in this chapter; not the voice of the dispassionate, analytic and detached academic, but rather, the voice of someone who has worked closely with this organisation for much of my academic life: I have had an entanglement with Bawinanga for a long time and I lament its decline.

Next I describe the shifting nature of Bawinanga according to a selection of the many texts produced by the corporation itself. Then I say something about what Bawinanga did, focusing my attention on a decade-long period of relative growth and stability when it had a 'vibrant life' to 2009 when it went into decline. I explore and look to critically theorise the reasons for Bawinanga's success according to both internal and external at arms-length assessments, including my own.

In this analysis, I highlight one short period 2005-06 when, after CDEP administration was transferred from ATSIC to DEWR, Bawinanga and DEWR engaged in a bitter political struggle that I refer to metaphorically as 'the CDEP wars'. Bawinanga struggled to gain acceptance for its approach to running CDEP, something that it had been doing with growing efficiency and confidence for 16 years before what I have termed 'metropolitan managerialism' (Altman 2005) bore down on the organisation from distant Canberra, as far away bureaucrats sought to impose a particular interpretation of the imagined failings of CDEP on Bawinanga. Evidence of this dispute is on the parliamentary record that I visit to ask: Why it is that expert and local knowledge have been disqualified or discarded as legitimate forms of knowing about CDEP?

I then provide a brief account of the rapid decline of Bawinanga from 2009 until 2012 when it went into special administration. I end by assessing what has been lost and by speculating whether the belated attempts to revive CDEP from late 2015 as the Community Development Program (CDP), linguistic similarities aside, might revive the fortunes of Bawinanga. 


\section{Entanglements: Bawinanga and me}

Over the years I have written a great deal about Bawinanga. I have also worked for Bawinanga as a consultant and advocated hard for Bawinanga including by assisting the corporation as the joint plaintiff in a High Court case Wurridjal v Commonwealth over the compulsory leasing of Aboriginal land during the Northern Territory (NT) Intervention and in submissions to and as an expert witness in parliamentary inquiries.

I have repeatedly visited the Maningrida region since 1979. My research has been heavily divided between working with a regional community of Kuninjku-speaking people first and foremost (many of whom are also members of Bawinanga) and working with Bawinanga.

The history of my intellectual and formal engagement with Bawinanga over the past 37 years is lengthy and complex. Suffice to say, I have personally known every chair of Bawinanga since 1979, most board members and most members of the senior management team, some of whom are friends with whom I have co-resided on many occasions when visiting. Over the years, I have also got to know many Indigenous and non-Indigenous residents of the region, which currently has a population of over 3,000.

I relate this to be quite transparent and disclose my abiding interests. I am sure there are some who view my close allegiances to Bawinanga with suspicion and as a weakness because it might foreclose openness to alternate viewpoints from other actors in the region. This may well be a valid criticism; I note though that I have worked with other organisations and have enjoyed cordial relations with their Aboriginal boards and staff despite shifting institutional rivalries and alliances typical of small-town politics and clearly evident over time in Maningrida. ${ }^{1}$ All these associations with Bawinanga have not stopped me from being a critical - sometimes highly critical — friend of Bawinanga and the operations of some of its business units, and being unpopular at times with board and management for providing frank advice.

1 I have worked in a voluntary capacity for the Maningrida Progress Association whose board I have also advised; and with the Maningrida Council until absorbed into the West Arnhem Shire in 2008 . 
I highlight these entanglements for two reasons. I want to write this chapter in a slightly different register, delving into a considerable archive of transcripts of Bawinanga's achievements, challenges and problems, especially focusing here on issues related to CDEP without replicating earlier writing on this subject (Altman \& Johnson 2000). I do this in particular by focusing on material contained in Bawinanga's narrative annual reports published 1999 to 2011 and its financial records. I am keen to bring material from this grey literature, Bawinanga's and my own archives, into the public domain highly conscious that there is a great deal more that can be said about Bawinanga's life cycle and circumstances. This particular contribution is very much intended as an economic history of Bawinanga's dialectical engagement with the CDEP scheme, how at once CDEP contributed to the making of Bawinanga and, conversely, how Bawinanga has demonstrated what could be done with CDEP and how paradoxically CDEP was instrumental in what I term here Bawinanga's 'near death' experience when it went into special administration.

On the final page of the postscript to a volume, The Indigenous Welfare Economy and the CDEP Scheme, ${ }^{2}$ that reported the proceedings of a large and mixed academic, bureaucratic and Indigenous community conference on CDEP, Rowse (2001b: 233) noted that there was urgent need for the articulation of an independent communitybased conception of what CDEP is all about. This was especially important, he suggested, as a counter to the government's dominant representation, as I have noted already, of CDEP as an employment scheme only. Rowse urged academics to play a role in formulating political and cultural rationales that CDEP managers could present to government. There has been considerable representation by Bawinanga and myself both before and after the 2001 volume, although its lack of influence is telling. Rowse also suggested in his postscript that CAEPR has a close proximity to the central agencies of government-perhaps geographically as both are based in Canberra, but not, as this chapter will demonstrate, in terms of ameliorating the destructive reform of CDEP.

2 To which the Bawinanga accountant Rupert Manners (2001) contributed a chapter on catering for mobility and diversity. 


\section{Bawinanga's objects and vision}

In his book Indigenous futures: Choice and development for Aboriginal and Islander Australia, which summarised and critically analysed CAEPR research 1990-2000, Rowse (2002) devotes a chapter to Indigenous institutions and the labour market. Rowse (2002: 67) highlights the many difficulties in defining the objects of CDEP because of its multiple rationales. At the time of his writing there were 270 CDEP organisations with over 30,000 participants nationally (Sanders 2004: 4).

A similar observation can be made of Bawinanga as a CDEP institution. Over its life, and in the words of its annual reports and constitution (now Rule Book), there have been changes over time. In its first narrative annual report for 1999-2000, an attempt is made to provide a brief overview of the corporation's history over the preceding 20 years (Johnson 2000: 1): 'initially Bawinanga was incorporated under the federal Aboriginal Councils and Associations Act 1976 as an outstation resource centre incorporating an earlier manifestation set up in 1974 as a branch of the Maningrida community council.' Johnson notes how in the 20 years since 1979 the corporation had expanded and diversified, not just providing support for up to 800 people residing at 32 outstations in the hinterland, but also administering CDEP with 512 participants and shifting to operate as a regional development agency establishing small commercial enterprises to promote economic development options for outstation residents and members. Johnson (2000: 1) further notes that the central tenet of all decisions made by the corporation is the maintenance of land, language and culture.

This statement of organisational philosophy was clearly stated after Bawinanga developed its first strategic plan 2004-06, a process facilitated by Dan Gillespie of Tallegalla Consultants (2003) with parts published in the corporation's annual report for 2003-04 (Johnson 2004: 6) in the following terms:

\section{Our Mission Statement}

Bawinanga Aboriginal Corporation's mission is derived from its constitution and is twofold:

- At the regional level we act as a force for the political integration and representation of the interests of over 100 regional land owning groups of our members 
- As a service delivery agency BAC provides cultural and natural resource management programs, essential municipal and social services and labour market and economic development opportunities to its members in Maningrida and surrounding outstation communities.

The maintenance of language and traditions and the management of and sustainable use of customary lands and resources underpin our work.

\section{Our Vision}

Our vision is to be:

- A successful agency for the representation and mediation of the interests of our members to other regional stakeholders, private enterprise and Government; and

- A leading Indigenous service delivery and business organisation managed by Aboriginal people for Aboriginal people and renowned for our innovation and best practice.

More recently, in the current Rule $B^{3}{ }^{3}$ the objectives of the corporation are defined in the following terms:

The objectives of the corporation are to provide services [to] the communities and lands set out in the map in Schedule 4:

a. to promote the maintenance of language, culture and traditional practice;

b. to promote the sustainable use of traditional lands;

c. to promote community development;

d. to promote the welfare of residents;

e. to provide or assist in the provision and maintenance of education, employment, housing, health, communications and other services;

f. to foster business opportunities and to promote economic independence;

g. to operate and maintain a gift fund to be known as - The Bawinanga Aboriginal Corporation Gift Fund in accordance with the requirements of the Income Tax Assessment Act 1997; and

h. to promote, in all its endeavours, the common good and mutual benefit of its members through fair, equitable and representative action and enterprise.

3 Available like much documentation about Bawinanga back to 2006 when the Aboriginal Councils and Associations Act 1976 was replaced by the Corporations (Aboriginal and Torres Strait Islanders) Act 2006 at register.oric.gov.au/document.aspx?concernID $=100029$, accessed 21 September 2015. 
The map referred to is a version of the following Fig. 7.1.

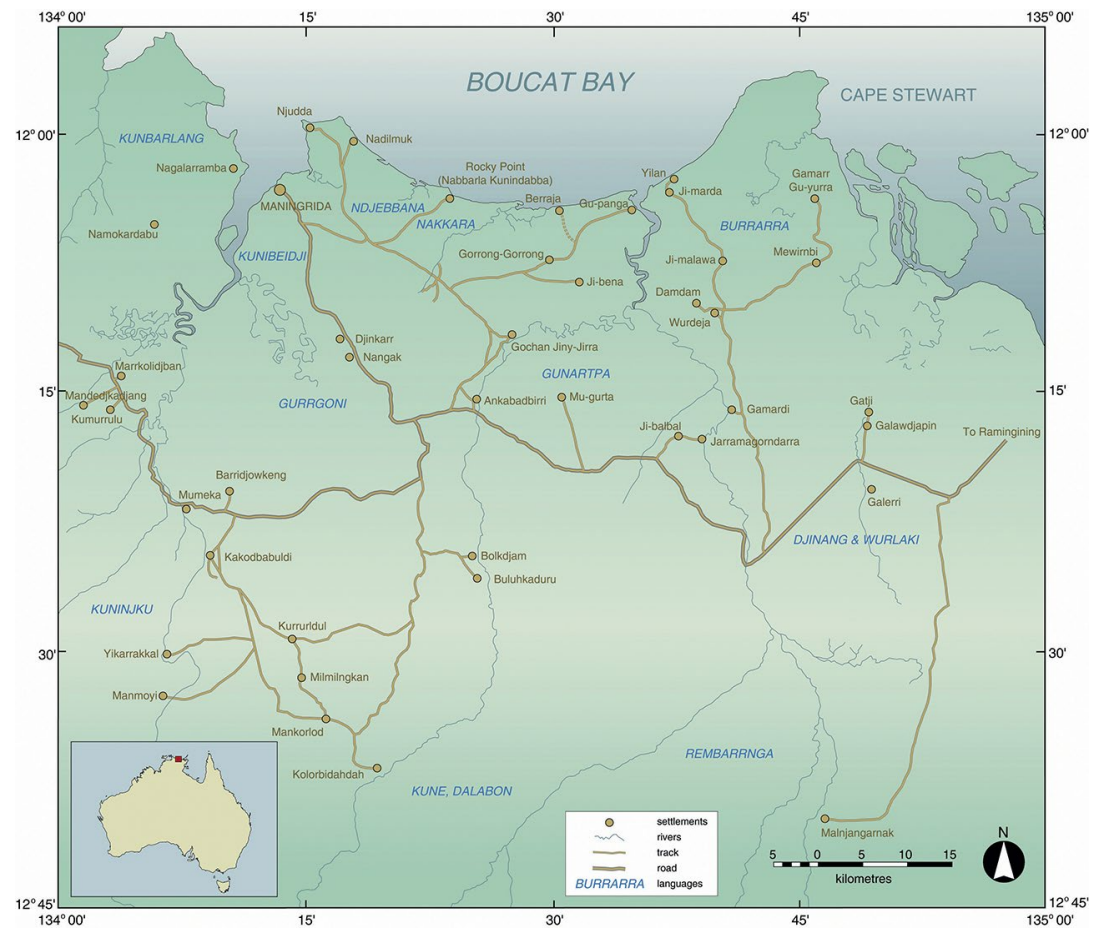

Fig. 7.1 A version of the map in Schedule 4 of BACs 'rule book'

Source: Map drawn for author with material provided by Bawinanga Aboriginal Corporation.

Such fine aspirational statements are not unusual, but in Bawinanga's case they have some important implications. First, given that the region of about $10,000 \mathrm{sq} \mathrm{km}$ is all Aboriginal-owned land, ${ }^{4}$ the corporation clearly has a major political role to play in mediating land owner interests, although in formal and legal terms this is the statutory responsibility of the Northern Land Council. Second, the objectives of Bawinanga extend beyond its membership (which numbers about 200 registered adults aged over 18 years) to include other non-member residents of the region. This reflects how Bawinanga has increasingly operated.

4 Barring a few special purpose leases and public lands in Maningrida that predated passage of the Aboriginal Land Rights (Northern Territory) Act 1976. 


\section{Bawinanga 1999-2010}

In 2000, I undertook a detailed review with Victoria Johnson of the Bawinanga CDEP as part of a wide-ranging study that included the above-mentioned conference, 'The Indigenous Welfare Economy and the Community Development Employment Projects (CDEP) Scheme: Autonomy, Dependence, Self Determination and Mutual Obligation' with proceedings subsequently published (Morphy \& Sanders 2001). Johnson had been employed by Bawinanga between 1998 and 2000 and the corporation was a financial and in-kind contributor to the review that ended with a set of recommendations, including that there is need for quarantined resourcing for more effective outcomes monitoring (Altman \& Johnson 2000: xi, 33).

On completion of the review, senior management at Bawinanga engaged Johnson to produce the corporation's first narrative annual report. Subsequently, as shown in Table 7.1, 11 further reports were prepared with 10 published. The 2000-01 annual report included the recommendations from the CDEP review. From 2003-04, after early resistance from senior management, the annual report included some summary financial statements from the corporation's audited accounts. From 2005-06 the annual reports became more political as transcripts with a Chairman's message and CEO's report that engaged with current policy settings and challenges.

Table 7.1 Bawinanga annual reporting 1999-2011

\begin{tabular}{|l|l|l|l|}
\hline BAC annual report & Author/compiler & Published & Pages \\
\hline $1999-2000$ & V Johnson & 2000 & 28 \\
\hline $2000-2001$ & V Johnson & 2001 & 18 \\
\hline $2001-2002$ & A McCall & Incomplete & 23 \\
\hline $2002-2003$ & V Johnson & 2003 & 28 \\
\hline $2003-2004$ & V Johnson & 2004 & 28 \\
\hline $2004-2005$ & C McAuliffe & 2005 & 32 \\
\hline $2005-2006$ & W Manners & 2006 & 34 \\
\hline $2006-2007$ & W Manners & 2007 & 32 \\
\hline $2007-2008$ & W Manners & 2008 & 32 \\
\hline $2008-2009$ & W Manners & 2009 & 32 \\
\hline $2009-2010$ & C Summers & 2010 & 57 \\
\hline $2010-2011$ & C Summers & 2011 & 65 \\
\hline
\end{tabular}

Source: Prepared by the author. 
All the authors of annual reports had worked for Bawinanga and so were able to compile information provided by the heads of business units. I was recently informed by Ian Munro, the Bawinanga instigator of such annual reporting, that in general 500 copies of the report were printed with a copy sent to every federal and Northern Territory politician. ${ }^{5}$

It is hard to know how to capture the wide range of activities reported in nearly 400 pages over this 12-year period, including vividly descriptive colour photographs that illustrate the degree of local people's pride in the corporation. ${ }^{6}$ Furthermore, these annual reports, as valuable a record as they are, only represent a series of snapshots of what ended up being a decade-long cumulative and incremental growth of the corporation and its social, physical and developmental capitals. $^{7}$

In an attempt to capture the complexity of Bawinanga, I have prepared a synoptic table of its range of activities that fall into three categories: activities that have ended; activities that have begun at some point during the period; and those that are core activities that continued throughout the period. To some extent, this approach has introduced some room for error as some activities are not reported even though undertaken. And it has also resulted in under-reporting because some smaller, but still important, activities are not separately reported.

An example of such a small but symbolically important activity is the mud-brick factory that is an iconic CDEP enterprise that began in 1989. In a comprehensive feasibility study report, Dan Gillespie of Tallegalla Consultants (2009: 1, 9) notes that the enterprise has provided employment continuously for up to 15 Indigenous people for almost 20 years. To date, over 130 buildings have been constructed from mud-brick, including a range of housing types and other

5 Ian Munro pers. comm. June 2015. Munro also related to me how on one occasion a staff member spotted Claire Martin, then Chief Minister of the NT, reading a Bawinanga annual report on a flight from Alice Springs to Darwin.

6 Obviously the annual reports were largely produced for external audiences and reflect what might be thought of as 'whitefella' accountability. But there has also been a degree of pride expressed especially by members of the Bawinanga board about the reports.

$7 \quad$ A spreadsheet assets register prepared in 2008 as part of the Wurridjal v Commonwealth case that I have lists all Bawinanga's fixed and non-fixed assets, which totalled nearly 600 items and were valued at over $\$ 24$ million - the main fixed assets include 100 outstation buildings and numerous houses and business premises in Maningrida. 
facilities at outstations, housing for Bawinanga and other agency staff, commercial and office buildings for Bawinanga and the Maningrida Progress Association, and major buildings such as the Maningrida Motel and Aged Care facility operated by the Malabam Health Board.

Furthermore, a lot of activity has been subsumed in one category. For example, under financial and related services, the 2006-07 annual report shows that Bawinanga assisted members and staff with online banking, internet banking, truck accounts (of which there were 200, or one-third of the CDEP payroll saving for vehicles), bill saving authorised deductions from CDEP, ceremonial support, again via payroll deductions, assistance to borrow money and assistance to access services (Manners 2007; Fogarty \& Paterson 2007).

The message from this table is that over the decade covered, community services and businesses were established that provided CDEP participants with meaningful activity destinations and the means to earn additional income. While during these years there were some variations, on average Bawinanga had 600 participants who fell into four categories: those employed by Bawinanga (about 200); those hosted by other Maningrida agencies and organisations like the school and health board (about 50); about 300 getting income support at outstations (who generally supplemented their CDEP payments with art sales to Maningrida Arts and Culture); and the balance of about 50 who received basic income support while on CDEP.

Rupert Manners (2001: 211-13) explains how this worked, although there have been many adaptive variations over the years approved by the board, particularly of the 'no work no pay' rule that was a critical element of attempts to manage labour. In general, there were three pay rates: one for participants who were supervisors; one for those who were working or training; and another for those at outstations. And then there were variations in hours: those at the highest two award plus pay rates could work for up to 4.6 hours a day for three days on CDEP and then get additional top up, including for extra days of work; those at outstations but also at funerals, ceremonies, sick, on maternity leave or working as a medical escort were paid for 3.6 hours a day; and, those referred to as on 'sit down' would get only 2 hours a day and would only be eligible for such payments under CDEP for a short time before being redirected to Centrelink for welfare. 
7. BAWINANGA AND CDEP

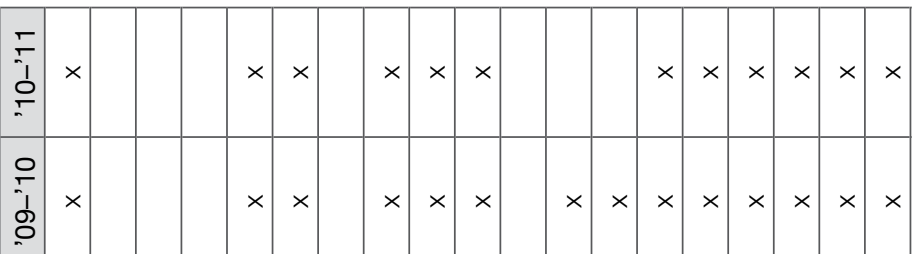

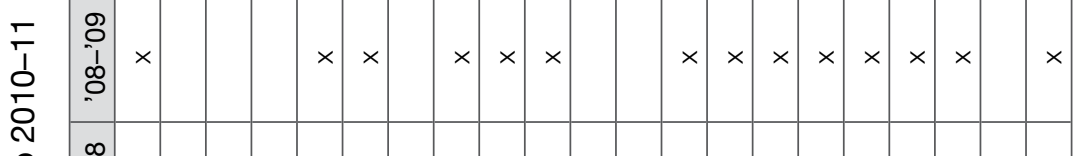

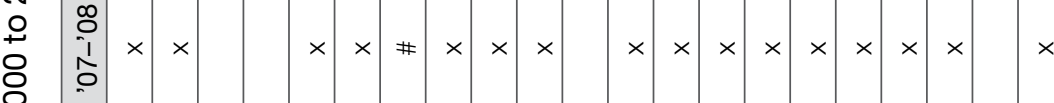

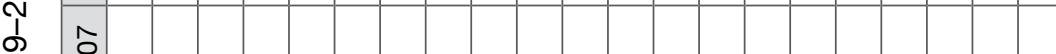

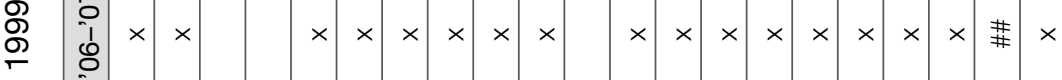

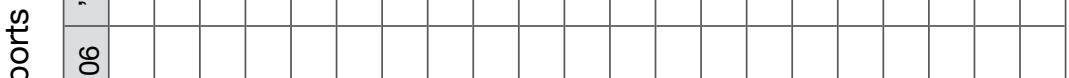

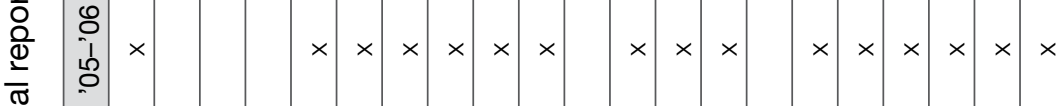

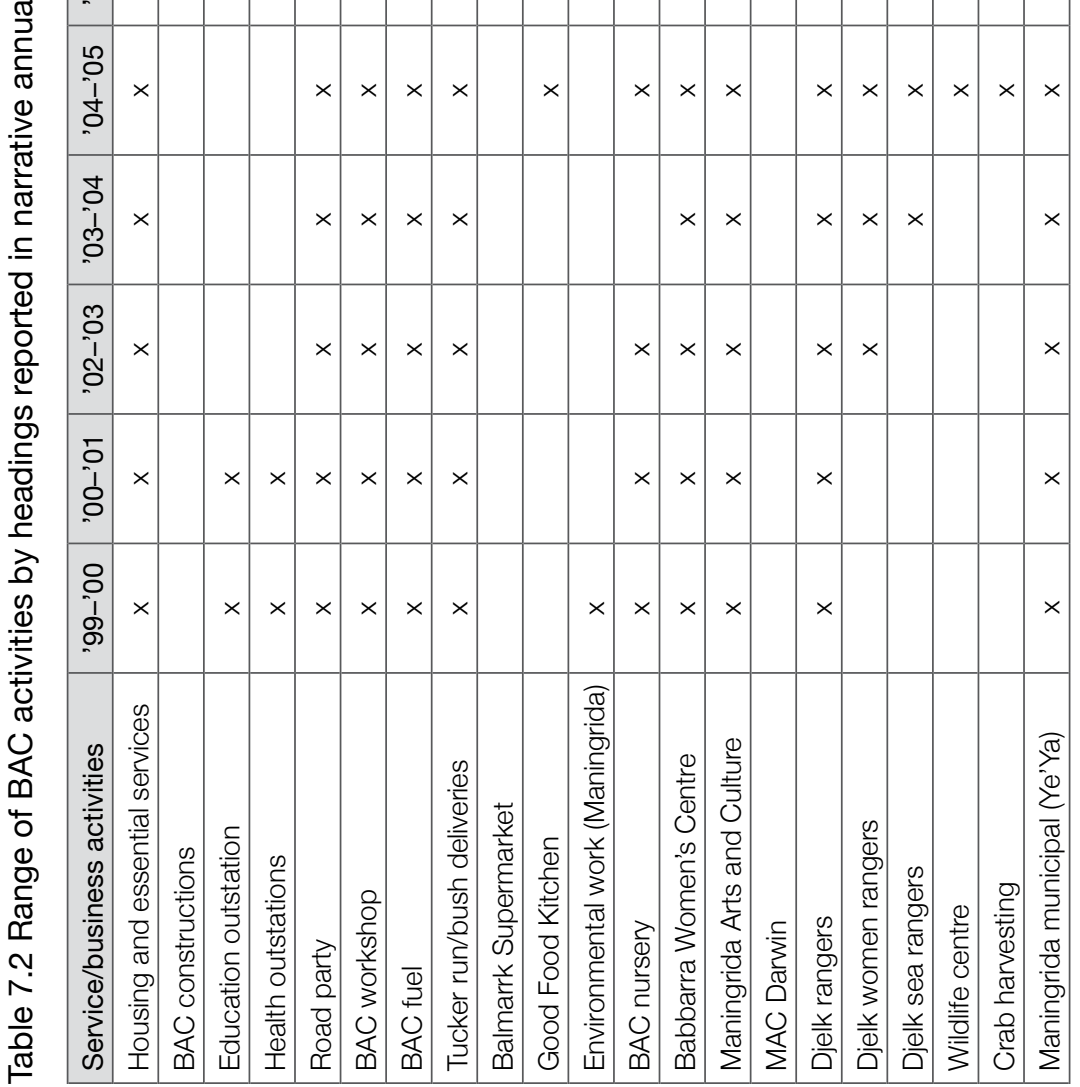


BETTER THAN WELFARE?

\begin{tabular}{|c|c|c|c|c|c|c|c|c|c|c|c|c|c|c|c|c|c|c|}
\hline 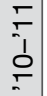 & & & & $\times$ & & & $\times$ & & $\times$ & $\times$ & $\times$ & & & $\times$ & $\times$ & $\times$ & $x$ & \\
\hline $\begin{array}{l}\bar{r} \\
1 \\
8 \\
0\end{array}$ & & & & $\times$ & & & $\times$ & & $\times$ & $\times$ & $\times$ & & $\times$ & $\times$ & $\times$ & $\times$ & & \\
\hline $\begin{array}{l}0 \\
0 \\
1 \\
0 \\
0\end{array}$ & & & & $\times$ & & & $\times$ & & $\times$ & $\times$ & $\times$ & $\times$ & $\times$ & $\times$ & & & & \\
\hline $\begin{array}{l}0 \\
0 \\
1 \\
\vdots \\
0\end{array}$ & & & & $x$ & & & $\times$ & & $\times$ & & $\times$ & $\times$ & $\times$ & & & & & \\
\hline $\begin{array}{l}1 \\
1 \\
0 \\
0\end{array}$ & & $\times$ & & $\times$ & & & $\times$ & & $\times$ & & $\times$ & & $\times$ & & & & & \\
\hline $\begin{array}{l}8 \\
0 \\
1 \\
20 \\
0\end{array}$ & & $\times$ & & $\times$ & & $x$ & & $x$ & $\times$ & $\times$ & $\times$ & & $\times$ & & & & & \\
\hline $\begin{array}{l}5 \\
0 \\
1 \\
0 \\
0\end{array}$ & & $\times$ & & $\times$ & $\times$ & $\times$ & & & $\times$ & $\times$ & & & & & & & & $\begin{array}{l}\frac{0}{t} \\
\frac{0}{0} \\
\frac{8}{2}\end{array}$ \\
\hline $\begin{array}{l}0 \\
0 \\
\text { Dे } \\
0\end{array}$ & & $\times$ & $\times$ & $\times$ & $\times$ & & & & $\times$ & $\times$ & & & & & & & & $\begin{array}{l}\text { है } \\
\text { ฮ } \\
\text { 을 }\end{array}$ \\
\hline $\begin{array}{l}0 \\
0 \\
1 \\
\text { ô. } \\
0\end{array}$ & & $\times$ & $x$ & $\times$ & $\times$ & & & & $\times$ & & & & & & & & & $\begin{array}{l}\text { 을 } \\
\overline{0} \frac{0}{0} \\
\frac{0}{0} \frac{0}{0}\end{array}$ \\
\hline $\begin{array}{l}5 \\
0 \\
1 \\
0 \\
0\end{array}$ & $\times$ & & & & & & & & & & & & & & & & & 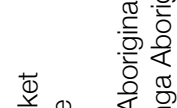 \\
\hline $\begin{array}{l}8 \\
0 \\
1 \\
8 \\
\end{array}$ & & & & & & & & & & & & & & & & & & 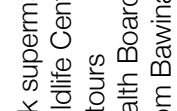 \\
\hline 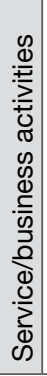 & 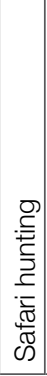 & 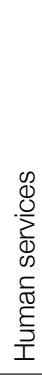 & 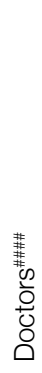 & $\begin{array}{l}\mathbb{1} \\
\frac{1}{0} \\
0 \\
\text { d } \\
\frac{1}{4}\end{array}$ & 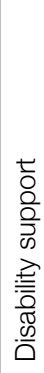 & 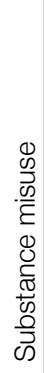 & $\begin{array}{l}\frac{\lambda}{0} \\
\frac{4}{\pi} \\
0 \\
0 \\
\frac{0}{\bar{D}} \\
0\end{array}$ & 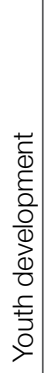 & 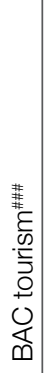 & 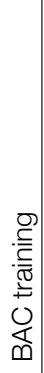 & 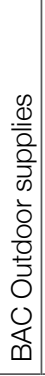 & 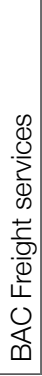 & 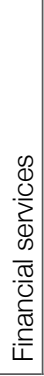 & 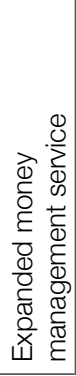 & 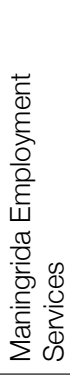 & 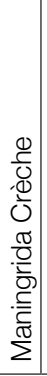 & 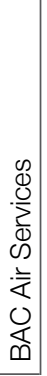 & 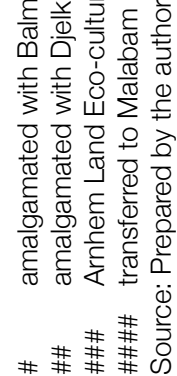 \\
\hline
\end{tabular}


Managing the tension between the corporation's rules around CDEP payments and the diverse aspirations of its members should not be understated. There was continual negotiation between the board, management and membership over the years and some minor changes, but as a general rule some version of the three-tiered arrangement was maintained.

These guidelines were discussed by supervisors and management and approved by the board. In the mid-2000s, Bawinanga businesses were paying CDEP participants extra wages of $\$ 1-2$ million per annum, while by 2007-08 Maningrida Arts and Culture was purchasing art from several hundred artists for well over $\$ 1$ million per annum, although not all were on CDEP.

Under the Bawinanga umbrella were some of remote Indigenous Australia's most successful cultural and land management entities, each developed and underwritten by CDEP. Some of these entities produced their own discrete annual reports for a number of years as a marker of institutional maturity. These include Maningrida Arts and Culture, which provided arts market brokerage to hundreds of artists from Maningrida and the region (e.g. see Kohen 2007; Kohen \& Summers 2008), and the Djelk Rangers. The Djelk Rangers were sustained by CDEP for over 10 years before they were moved onto Working on Country program wages in 2007; they began managing the Djelk Indigenous Protected Area when declared in 2009 (see Pascal \& Ansell 2009; May, Ansell \& Koenig 2010).

The complexity of Bawinanga is also reflected in financial transcripts - its annual audited financial statements. In 2005-06 and 2006-07, these audits were undertaken by Chartered Accountant Frank Redpath, with information provided by Bawinanga's accounting and bookkeeping team. I use these two years as an illustrative example because audits were prepared in a particularly comprehensive and detailed manner at the time, covering over 100 pages that gave a sense of both the scale and financial complexity of the corporation. In 2006-07, Bawinanga was managing 56 grants and contracts, the most significant by far being CDEP wages at $\$ 6.7$ million (for 600 
participants) and CDEP operational at $\$ 2.5$ million. ${ }^{8}$ It also had 21 trading accounts, 17 that were profit-making and three that were lossmaking.

The four big profit-makers that year were the supermarket $(\$ 750,000$ profit), Maningrida Arts and Culture $(\$ 487,000)$, road contracting $(\$ 467,000)$ and the fuel store $(\$ 138,000)$. The loss-makers were small, only bush deliveries $(\$ 82,000)$, BAC tourism $(\$ 27,000)$ and MAC Darwin $(\$ 21,000)$ stand out. Clearly the profits outweighed the losses that year and, indeed, for most years (see Table 7.3).

There are two crucially important features of Table 7.3. In almost every year Bawinanga's trading and other income exceeded its grants income, quite a remarkable achievement in the context of remote Indigenous Australia. This meant that at the very least it was able to capture a significant proportion of the funding coming into the region and generate profit for regional benefit. While exact figures are not readily available for all financial years, during most years CDEP funding accounted for almost 80 per cent of non-trading income - this was the big, core funding fundamental to Bawinanga's success, mainly made up of notional equivalents of welfare and its administration. ${ }^{9}$

And during most of what I term 'the period of vibrancy', Bawinanga increased its turnover in both real and monetary terms and until 2011-12 generally ran small profits after accounting for depreciation. Tallegalla Consultants (2009: 4) notes that the corporation's turnover exceeded $\$ 30$ million for the first time in 2007-08. It has been noted that the corporation's turnover was more than half of the revenue of the Darwin City Council and 50 per cent more than the revenue of the Alice Springs Town Council (ACIL Tasman 2007: 12).

8 As noted earlier, once CDEP was transferred from ATSIC it was not a grant per se, but rather a contract awarded after competitive tender.

9 Ian Munro (pers. comm. 11 July 2015) notes that while CDEP income was a big number, from the mid-2000s BAC actually had to use discretionary resources to cover some administration of the program as government formula-based funding was inadequate. CDEP in and of itself was not inherently 'profitable'. 
Table 7.3 BAC grants, trading and other income, and total income 2000-01 to 2013-14

\begin{tabular}{|l|c|c|c|c|c|c|}
\hline Year & $\begin{array}{c}\text { Grants } \\
\text { (\$ million) }\end{array}$ & $\%$ & $\begin{array}{c}\text { Trading and } \\
\text { other income } \\
\text { (\$ million) }\end{array}$ & $\%$ & $\begin{array}{c}\text { Total income } \\
\text { (\$ million)\#\# }\end{array}$ & $\begin{array}{c}\text { Surplus } \\
\text { (deficit) } \\
\text { (\$ million)\#\# }\end{array}$ \\
\hline $2000-01$ & 8.2 & 48 & 7.9 & 52 & 17.1 & $\mathrm{n} / \mathrm{a}$ \\
\hline $2001-02$ & 9.6 & 56 & 7.4 & 44 & 17.0 & $(0.19)$ \\
\hline $2002-03$ & 9.2 & 47 & 10.6 & 53 & 19.7 & 0.12 \\
\hline $2003-04$ & 10.5 & 46 & 12.1 & 54 & 22.6 & $(0.11)$ \\
\hline $2004-05$ & 11.6 & 44 & 14.7 & 56 & 26.3 & 0.95 \\
\hline $2005-06$ & 11.7 & 45 & 14.5 & 55 & 26.2 & $(0.3)$ \\
\hline $2006-07$ & 12.2 & 45 & 15.1 & 55 & 27.3 & 1.1 \\
\hline $2007-08$ & 13.6 & 44 & 17.0 & 56 & 30.6 & 0.2 \\
\hline $2008-09$ & 15.8 & 47 & 18.0 & 53 & 33.8 & 0.5 \\
\hline $2009-10$ & 14.2 & 39 & 21.6 & 51 & 36.6 & 1.4 \\
\hline $2010-11$ & 18.1 & 47 & 19.9 & 53 & 38.6 & 2.7 \\
\hline $2011-12$ & 15.2 & 43 & 20.1 & 57 & 35.3 & $(4.0)$ \\
\hline $2012-13$ & 15.6 & 51 & 14.5 & 49 & 30.3 & $(7.6)$ \\
\hline $2013-14 \#$ & 10.3 & 32 & 21.5 & 68 & 31.8 & 0.5 \\
\hline
\end{tabular}

\# Inclusive of $\$ 3.5$ million loan from MPA and grant balance write-off and audit reversal of $\$ 6$ million.

\#\# The consumer price index increased between June 2001 and June 2014 by 42 per cent, see www.abs.gov.au/websitedbs/d3310114.nsf/home/Consumer+ Price+Index+Inflation+Calculator, so 2000-01 turnover of \$17.1 million was worth \$24.2 million in June 2014.

\#\#\# Net of depreciation.

Source: Prepared by the author from Bawinanga Aboriginal Corporation annual reports.

\section{The Bawinanga approach to CDEP success}

In 1985, the Miller Review of Aboriginal Employment and Training Programs (Miller 1985) was commissioned to undertake the first comprehensive review of the labour market situation of Aboriginal people Australia-wide. As noted in Chapter 4, Miller recommendations laid the foundations for the Aboriginal Employment Development Policy and the late 1980s expansion of CDEP. It was conducted during the self-determination era and during the progressive Hawke Government years and was sympathetic to the fundamentally different needs of remote-living Aboriginal people. 
The Miller Review made numerous recommendations that I summarise as follows. First, it differentiated settled from remote Australia. Second, it was sympathetic to the aspirations of Aboriginal people to live on the land that they owned and to pursue diverse strategies for livelihood, including in the non-market sector. Third, it saw the issue of work in remote Australia holistically, understanding that the economic base needed to be built slowly and employment generation integrated with community development, especially in situations where there were no mainstream labour markets and limited commercial opportunity. Along with the Blanchard Report, Return to Country, some two years later, which examined the homelands movement in Australia (Blanchard 1987), these two national inquiries greatly influenced the developmental approach taken by Bawinanga.

Twenty years later, in 2005, the House of Representatives Standing Committee for Aboriginal and Torres Strait Islander Affairs (HRSCATSIA) was asked to inquire into positive factors and examples among Indigenous individuals and communities that improved employment outcomes (HRSCATSIA 2007: xiii). This inquiry began just after the abolition of ATSIC and ended some two years later just before the Northern Territory National Emergency Response Intervention (the NT Intervention). I will return to this inquiry later, I bring it up here because Ian Munro, then General Manager of BAC, made a submission (no. 20) in April 2005 and subsequently members of the inquiry committee visited Maningrida to take verbal evidence in July 2006 from board members and Munro, who was by then CEO. ${ }^{10}$

In seven pages of submission (Munro \& Manners 2005) and evidence delivered to the committee in Maningrida on 17 July 2006, ${ }^{11}$ elements of the Bawinanga CDEP model were outlined. To briefly paraphrase, the evidence tendered highlighted how Bawinanga had achieved employment outcomes by creating a job market where one did not formerly exist. A short document prepared for DEWR by Munro

\footnotetext{
10 To be transparent I also made a submission (no. 88) to the committee in May 2005 (some 20 years after I had made a submission to the Miller Inquiry) and gave verbal evidence in Canberra on 13 February 2006. My written submission focused on official statistics demonstrating the success of CDEP generally, my oral evidence was more specific and used much material about Bawinanga_see www.aph.gov.au/Parliamentary_Business/Committees/ House_of_Representatives_committees?url=atsia/indigenousemployment/hearings.htm.

11 Available at www.aph.gov.au/Parliamentary_Business/Committees/House_of_Representatives _committees?url=atsia/indigenousemployment/hearings.htm, accessed 21 August 2015.
} 
and Rupert Manners-BAC's financial controller-emphasised that the development of commercial enterprises is a cornerstone of the Bawinanga model. Munro and Manners (2005) note:

[o]ur operations provide training and employment opportunities, deliver efficient services to the community, address consumer demand, and generate profits which can be reinvested in local economic growth. Managers are required to demonstrate a commitment to economic growth constrained only by cultural considerations, the shortage of development capital, and the need to avoid disproportionate levels of non-Aboriginal employment.

Later they note:

[c]ultivation of the regional economy is somewhat challenging, requiring a degree of anthropological knowledge, an intimacy with the funding matrix and a willingness to speculate scarce capital on untested ventures remote from markets. We have had our share of business failure. It will always be so.

At the heart of the model were three components: responsiveness to local aspirations and realism about cultural priorities of its members; the skilful deployment of CDEP labour; and the prudent investment of corporation profits in commercial and social enterprises.

In 2009, as he was planning to move on, CEO Ian Munro approached the NT Government's Department of Housing, Local Government and Regional Services, suggesting that a consultant be commissioned to document Bawinanga's success and transportability to other communities. Peter Anderson Consulting Pty Ltd was commissioned and provided a report with the Jonathan Swift-like title, ${ }^{12}$ Bawinanga Aboriginal Corporation Achievements Review in order to identify practices which might productively be pursued elsewhere in remote areas of the Northern Territory, dated May 2010 (Anderson 2010).

Peter Anderson was an interesting choice of consultant. He had lived in Maningrida as a child, had undertaken a number of business planning assignments in Maningrida for BAC and other agencies and was an

12 A Modest Proposal for Preventing the Children of Poor People From Being a Burthen to Their Parents or Country, and for Making Them Beneficial to the Publick (1729). 
associate of ACIL Tasman, who had undertaken a report Business Opportunities in the Maningrida Area commissioned by Bawinanga in 2007. ${ }^{13}$

Anderson's report is not widely available but provides an arms-length perspective based on a critical engagement with a selection of the literature about Bawinanga and interviews with a diverse range of Indigenous and non-Indigenous stakeholders, including me.

Focusing on employment, Anderson notes that there are three ways to increase this, excluding outmigration that is not a local preference: the replacement of balanda (non-Indigenous) employees, but this will be slow at best due to a local skills deficit; increased subvention by government, something that happened during the Intervention but at insufficient levels; and/or through the creation and operation of sustainable enterprises. Anderson notes that in 2010 there were 600 CDEP participants and 200 non-CDEP Maningrida jobs, further noting that the conversion rate does not add up (Anderson 2010: 19). In 2010, when CDEP was already in rapid decline, Anderson notes that Bawinanga was highly vulnerable because of its high dependence on the scheme. This observation was hardly insightful as the corporation had already experienced this vulnerability some five years earlier.

\section{The CDEP wars: Metropolitan rationalism versus remote realism}

The greatest challenge in the coming year will undoubtedly be the need to maintain the trajectory of our CDEP success. The demise of ATSIC has seen CDEP move to the Department of Employment and Workplace Relations. Regrettably, DEWR's inexperience and lack of understanding of Aboriginal people and communities threatens to destabilise the successes of our CDEP. We need to work with DEWR and other Government departments to ensure that continued support results in outcomes which are realistic, achievable and appropriate. (Otto Campion, Chairman's message prefacing the BAC annual report 2004-05 in McAuliffe 2005: 2)

13 Peter Anderson had also worked for me as a sub-consultant when I undertook the MAC Business Development Plan in 1999 and was the CEO appointed by KordaMentha for a short time between July and October 2013 when Bawinanga was still in special administration. He is also a friend of David Bond who had been CEO for 24 years from late 1980 to 2005. 
There has been major conflict between BAC and the Department of Employment and Workplace Relations (DEWR) over the operations of the CDEP program, resulting in their decision in June this year to discontinue our CDEP funding. Following strong representations by BAC, funding has been reinstated but tensions continue. The gulf between us relates principally to the question of 'real jobs'. It is the stated objective of BAC to attain unsubsidised employment for all CDEP participants. The means by which this can be achieved forms the basis of the entrenched dispute with DEWR. (Ian Munro, CEO Report, BAC Annual report 2005-06 in Manners 2006: 8-9)

Much of the employment policy debate in the post-ATSIC era has focused on whether CDEP jobs are 'real' jobs; and whether such jobs result in government agencies and others reneging on their obligations to Indigenous Australians as citizens by utilising CDEP labour paid for with notional welfare equivalents (for a discussion of the former issue see Chapter 5).

In a review of research on CDEP undertaken by researchers at CAEPR, Rowse (2002: 65-78) argues that a policy focus on 'the individual' and individual welfare has obscured the non-labour market outcomes of the CDEP scheme. I concur. The material provided in this chapter demonstrates the range of these non-labour market outcomes in relation to Bawinanga, including social externalities, community development and social and cultural outcomes. Rowse suggests that a CDEP scheme is a form of Indigenous authority: as CDEP organisations mediate between government and participants, they exercise authority over workers and become players in the regional political field. In short, they are a form of local or regional political authority whose relationship with government is open to negotiation. That is the way it was in 2002, although I would add that CDEP organisations, like Bawinanga in their regional development manifestation, are also political economy institutions.

In his postscript to the Indigenous Welfare Economy volume already mentioned, Rowse (2001b) made three points that seem especially pertinent now with the benefit of hindsight observing developments over the following 15 years.

Even back then, Rowse noted the emerging use of what he termed the jargon of the 'real' economy as employed by Noel Pearson (2000). Rowse warned that this jargon needed to be critically challenged lest a view emerged that CDEP work was less 'real' than other forms 
of employment. This warning, as I will show, was prescient because the language of the 'real' economy and 'real' jobs has become ubiquitous, even naturalised, in Indigenous policy over the last decade and a half - in Canberra it is hard to come across a politician or bureaucrat who does not use the term. As Rowse notes, and again I concur, there is nothing necessarily 'second-best' about CDEP work.

A related point that Rowse (2001a, 2001b, 2002) highlights is that the CDEP scheme was never just about employment and must be recognised as having multiple objectives. Yet the scheme has always struggled for recognition of this difference, not just because it does not fit neatly into bureaucratic boxes as Sanders (2001) suggests, but also because it challenges the new 'normalisation' direction of Indigenous policy (Altman 2014).

Finally, Rowse (2001b) notes that CDEP was in a strong position because if government decided to abolish the scheme (which it has now done) then what would replace it? Rowse suggested that CDEP was doing so many necessary jobs in so many different ways in so many places that it was quite entrenched in the Australian system of government. It may not have been getting the recognition it deserved but it was going to be hard to get rid of. But get rid of it government did.

The process of abolition began in earnest on 1 July 2004, but took over a decade to complete. Sanders (2004) noted the danger of these new administrative arrangements and predicted that CDEP would sit uncomfortably in the employment portfolio, warning that because DEWR had a strong employment and labour market focus it would lose patience and interest in the community development and income support aspects of CDEP.

In my view, Sanders' analysis was a little too benign because he interpreted the prospects for CDEP within DEWR in terms of bureaucratic politics only, somewhat detached from the broader political context and the new managerialism identified by Sullivan (2011).

This became very clear to me late in 2004 when, in my one and only formal meeting with then secretary of DEWR Peter Boxall (and Bob Harvey, his lieutenant charged with CDEP reform), he defended his economic rationalist view that CDEP participants could be forced by market signals into mainstream employment either in community or 
through labour migration. ${ }^{14}$ This reflected the emerging domination that Rowse $(2001 \mathrm{~b})$ had identified, a shift in policy thinking for remote Australia from a focus on community-building to a focus on the individual, as if the two are somehow separable. But this heightened focus on the individual and agency has increasingly ignored the politico-structural circumstances in remote Indigenous Australia, as well as in parts of more settled Australia (as argued in Chapter 4). Those advocating for engagement in the 'real' economy have been careful to never precisely define what this constitutes in its actually existing form, choosing to ignore the views of local experts about local economic realities. Here was a clear triumph of ideology.

Just how this attempted reform played out in remote Australia can be demonstrated with reference to a bitter and complex political conflict that emerged in 2005 and 2006 between DEWR and Bawinanga. As Otto Campion noted in his Chairman's message at the start of this section, this conflict not only had the potential to destabilise growth and success to date but also to erode relations of trust and cooperation with key funding agencies. Locally, this conflict was referred to as 'the CDEP wars' (Altman 2005, 2008). While Rowse (2001a: 232) had previously noted a plea from CDEP organisations for respectful engagement from government agencies, there was nothing respectful in this exercise of raw fiscal and political power over a relatively small and successful Indigenous organisation.

At the heart of this dispute were conflicting views on how CDEP should be delivered in the Maningrida region. In correspondence to the Commonwealth Ombudsman dated 8 July 2006, Ian Munro, then CEO, noted that:

BAC feel that they have been dealt with unfairly by DEWR and we can cite instances of decisions apparently being influenced by malice within the ranks of DEWR staff. We believe that this stems from two things. First BAC has promoted our model of CDEP quite forcefully and DEWR resents the challenge to their policy. Secondly, the BAC model is inconsistent with the DEWR doctrine, and our obvious success diminishes the credibility of the DEWR preferred model (Munro 2006).

14 University of Chicago-trained Boxall has described himself as 'an unabashed rationalist' (Boxall 2012). Bob Harvey received a Public Service Medal 'for outstanding public service in implementing reforms to the Community Development Employment Projects program for Indigenous Australians www.gg.gov.au/sites/default/files/files/honours/ad/ad2007/medianotesPSM.pdf. 
I cannot dwell in too much detail on this complex conflict. At its heart were divergent views about what constituted 'real jobs' and how many of its 600 CDEP workers Bawinanga should be exiting to unsubsidised and sustained mainstream work in Maningrida. The dispute flared on two occasions as Performance Funding Agreements had to be negotiated for the 2005-06 and 2006-07 financial years, and DEWR refused to approve these unless Bawinanga guaranteed to exit 30 and then 60 CDEP participants into mainstream employment. This was something that the board and senior management were unwilling to do with their knowledge of the severely limited Maningrida labour market and the aspirations of their CDEP participants and members. It was a clear case of realistic local knowledge about remote circumstances versus disconnected 'metropolitan managerialism' that looked to apply crude percentage formulas to funding agreements without proper assessment of local circumstances. This is a fundamental structural failing of the dominant economic system that cannot deliver despite the rhetoric of politicians and officials. And so the dominant then reconstrue this systemic failing as the personal shortcoming of the people who are the policy targets.

I use the term 'metropolitan' here because there was clearly a disconnect not just between DEWR and Bawinanga, but also between the Canberra headquarters and Darwin regional office of DEWR, and between DEWR and the highly unstable series of Commonwealth agencies in the immediate post-ATSIC era purportedly representing the interests of remote-living Indigenous people.

The low point in this dispute occurred in April 2006 around the time that Cyclone Monica, the most intense tropical cyclone on record to impact Australia, crossed the coastline near Maningrida. At this time, while Bawinanga was deploying CDEP labour to assist in the clean-up of a severely damaged Maningrida, DEWR was negotiating with the CEO of the Maningrida Council about the possible transfer of a proportion of CDEP participants from Bawinanga to the council, counter to the directions of elected councillors.

In correspondence dated 16 June 2006, the Maningrida Council wrote to Peter Boxall and made it quite clear that they did not support the unauthorised action of their CEO in his endeavours to see the council win back CDEP allocations that it had lost a decade earlier. DEWR was delving into community politics as a means to break the resistance of Bawinanga to its demands. 
A political highpoint of sorts occurred when Bawinanga Board members and senior management were afforded democratic opportunity to explain their successful approach and to place the dispute with DEWR on the public record as evidence to a parliamentary inquiry on Indigenous employment. Thirty pages of evidence provide rare insights, from a community perspective, on how local success can be jeopardised as part of a broader national agenda of imagined improvement. $^{15}$

The visit to Maningrida clearly had an impact on one member of this parliamentary inquiry, Danna Vale, Liberal Party MP for the electorate of Hughes in New South Wales. In a second reading speech on the Corporations (Aboriginal and Torres Strait Islander) Bill 2006 on 11 October 2006, she referred in some detail to Bawinanga and made the following summary comment:

The Bawinanga Aboriginal Corporation at Maningrida is an excellent example of a well-organised and well-managed Indigenous corporation that provides essential services to its people and initiates activities that create economic development, training and job creation. Its work is invaluable to the people of the Maningrida community. Reading through its recent annual report [2004-05], one sees that this corporation deals with income in the tens of millions of dollars, almost half of which is in the form of government grants. In his message, the chairman states that the success of these projects will rely on our commitment, vision and effort, supported by increased levels of government support. ${ }^{16}$

Unfortunately, these observations were not reflected in the final report Indigenous Australians at Work (HRSCATSIA 2007), where the considerable input of Bawinanga was given no attention and the issue of CDEP was largely overlooked. However, in a minority report by four members of the Australian Labor Party, Bawinanga was mentioned directly in relation to the importance of CDEP to its developmental work:

15 Available at www.aph.gov.au/binaries/hansard/reps/commttee/r9499.pdf, accessed 21 September 2015.

16 See parlinfo.aph.gov.au/parlInfo/download/chamber/hansardr/2006-10-11/toc_pdf/50173.pdf;fileType $=$ application $\% 2 F p d f \#$ search $=\% 22$ chamber $/$ hansardr $/ 2006-10-11 / 0016 \% 22$, accessed 2 July 2015. 
CDEP plays a critical role in this process [regional development] because it has had 'the flexibility necessary for the difficult tasks of growing the regional economy' in an area where there is no mining, manufacturing or agricultural activity and where the challenge of 'accommodating a willing workforce in relevant and productive employment requires creative and clever solutions.' The corporation, frustrated in finding other sources of funding, have used profits from their successful trading enterprises set up under CDEP to provide seed capital for business development and to top up wages. This may well represent a legitimate future direction for CDEP in communities with limited opportunities for conventional employment (HRSCATSIA 2007: 216-7).

These competing discourses raise a lot of questions not just about the turbulence of the Indigenous policy cycle, but also about the ability of politicians and bureaucrats to 'disqualify' (Foucault 1980) local and expert knowledge. The views expressed in the minority report did not, unfortunately, translate into policy change when the ALP was elected to government five months later, a reflection of the growing consensus in the neoliberal governmentality of remote Indigenous communities (Altman 2014).

\section{The Great Crash: Bawinanga's ‘near death’ experience}

There have been too many policy changes over the last few years, first as part of the Intervention and now with the reformed CDEP. We are overwhelmed, and find it difficult to keep up with the detail and understand how the policies will be implemented. Our members are unsettled and worry about the future. How will the reformed CDEP affect them and their families? What will happen after the program is phased out in 2011? (Jimmy Pascoe, Chairman's message prefacing the BAC annual report 2008-09 in Manners 2009: 3)

After 'the CDEP wars' policy changes occurred rapidly (as outlined in Chapter 2 and the annotated timeline in this volume). Three weeks after the parliamentary report was completed, the NT Intervention was announced and Bawinanga entered into other political battles with the Australian Government particularly in its organisational opposition to the Intervention. In July 2007, as an additional Intervention measure, Minister Brough announced that CDEP was to be abolished after he 
discovered that participants on wages could not be income managed. But then in November 2007 CDEP got some temporary reprieve with a change of federal government that then embarked on a reform agenda of its own, which saw CDEP fundamentally altered from July 2009 and then abolished from 1 July 2013 with the establishment of RJCP. ${ }^{17}$

In June 2009, Ian Munro, the manager who had overseen Bawinanga's rapid growth over the previous decade, left Maningrida worn down by 'the CDEP wars' and overseeing organisational opposition to the Intervention and in need of a break after 18 years at Maningrida. Unfortunately, he left without an appointed or suitably inducted successor and so for 12 months Bawinanga had a series of acting CEOs before Luke Morrish was appointed in mid-2010.

Munro's departure coincided with implementation of a new version of CDEP introduced by Jenny Macklin that signalled, in my view, the beginning of the end of Bawinanga's earlier success because it could not accommodate the flexibility it required.

This new approach divided participants into two streams - those engaged in community development and those engaged in job search. This division was imposed by the Rudd Government and so drastically reduced the autonomy of CDEP organisations to make their own decisions.

And, more significantly, two categories of CDEP participants within these two streams were created with a stroke of policy unilateralism. Those already on CDEP were 'grandfathered' as employed and as wage earners, while new CDEP entrants were limited to receive Newstart from Centrelink, classified as unemployed and not afforded the option to earn additional income without the disincentive of the social security taper - deprived of a significant benefit of CDEP participation locally referred to as 'top up'. ${ }^{18}$

17 As Thomas Michel reminded me in reviewing this chapter, in the midst of all this CDEP reform upheaval, the NT Government also introduced reform of local government with the amalgamation of 53 councils with predominantly Indigenous populations into eight regional shires with its own set of intended and unintended consequences (see Michel \& Taylor 2014).

18 See www.dss.gov.au/sites/default/files/documents/05_2012/cdep_program_guide.pdf. 
These changes not only affected the well-being of the many individuals who could no longer earn top up without losing some income support but also undermined their incentive to work. This resulted in Bawinanga struggling to recruit CDEP participants to its enterprises as they could not earn income above Newstart.

The modus operandi of Bawinanga shifted quite dramatically even though a number of CDEP participants, particularly those associated with outstations were grandfathered. Being grandfathered had a small added bonus as these participants were categorised as wage earners, and were thus not subject to compulsory income management, one of the purported reasons CDEP was to be abolished in July 2007 as an Intervention measure.

All the dire warnings that Bawinanga would become a fundamentally different organisation without CDEP came to fruition - the organisation went into fiscal decline. This decline can be explained by a combination of factors including the recruitment of a revolving door of new staff, some of whom did not live in community but commuted from Darwin; financial pressure on some of Bawinanga's iconic businesses, especially MAC, which after the Global Financial Crisis went from being a surplus-generating entity into a lossmaking liability (as analysed by Munro 2010); and the adoption of a fundamentally new approach by management to enterprise development that included establishing enterprises without rigorous business planning or a realistic assessment of risk.

The last factor represented a critical change in management approach from one based on organisational expansion and business development based on a stated vision, cultural understanding, client focus, sound risk assessment and risk management techniquesgood business practice - to poor business practice that lacked the personal commitment of management (except self-interest) or interest in the aspirations of the membership. It was, at its heart, based on either a genuine or cosmetic adherence to the neoliberal logic of the Intervention.

The most obvious departures from sound past practice were twofold. First, government funds allocated to specific purposes, especially CDEP wages, were carried over and allocated to non-CDEP purposes. These carryovers were reported in audited financial reports, but they 
did not trigger timely intervention either by the funding body - the Department of Families, Housing, Community Services and Indigenous Affairs - or by the regulator - the Office of the Registrar of Indigenous Corporations - with whom reports were lodged.

Second, even as businesses like Maningrida Arts and Culture were failing (Munro 2010), new ventures including BAC Air Services and the expansion of outstations services provision, first to the Ramingining region to the east and then to the Oenpelli region to the west, were established. Not only was such expansion over-ambitious, it was debt financed rather than being prudentially financed as in the past from organisational surpluses.

This new direction was signalled in BAC's last two published annual reports for 2009-10 and 2010-11, which indicated that Bawinanga was embarking on a new expansionary phase (see Sommers 2010, 2011). Arguably this new, somewhat reckless approach was forced on the corporation owing to external policy changes. Information in Table 7.3 shows financial details of Bawinanga's financial decline. In 2011-12 and 2012-13, the corporation was in unprecedented debt and in October 2012 it went into special administration because its cash flow situation had deteriorated to such an extent that it could not pay its staff, including CDEP workers. Not long before then, in July 2012, the board had terminated the contract of CEO Luke Morrish after only two years, during which time he had turned the corporation from one making profit to one that was deeply indebted.

I cannot analyse what has happened at Bawinanga since it went into special administration in October 2012 here in any detail, in part because these issues still (in August 2016) remain sensitive and inaccessible. Suffice to say that for a period Bawinanga became an organisation marred by opaque processes, deep uncertainty, high staff turnover, struggling businesses and an inability to effectively meet its diverse objectives. There have also been periodic tensions between the board-which, since 2014 has included two non-member directors appointed by the Registrar of Indigenous Corporations - senior management, staff and the members themselves over the direction the corporation should take and its key priorities. 
Under such circumstances it is perhaps unsurprising that there have been no annual reports published since 2010-11, a historical series that began in 1999-2000 and ended abruptly. Peter Anderson, when CEO in September 2013, told me Bawinanga had no resources to expend on such glossy documents. ${ }^{19}$

In the short term, Bawinanga has been rescued from winding up by the Australian Government 'shelving' a debt of over \$6 million and its main local 'competitor', the Maningrida Progress Association, providing a loan of $\$ 3.5$ million over five years to pay off private creditors.

Much information on Bawinanga's period of special administration (October 2012 to July 2014) is available at the website of the Office of the Registrar of Indigenous Corporations so this detail will not be recited here. ${ }^{20}$ The most recent audited financial statement for 2014-15, also on the Office of the Registrar of Indigenous Corporations website, shows that Bawinanga might be slowly recovering. To what extent it was changes in CDEP, as distinct from changes in Indigenous policy more generally, that had been responsible for Bawinanga's rapid decline is what I now turn to in conclusion.

\section{Challenging 'Regimes of Truth': Where to now for Bawinanga?}

When MPA time, we left Maningrida and went home to the bush. Then BAC came and all that time it was good with BAC. We worked with BAC but then the government rules changed and BAC started to change too. Then the government came and they made BAC do what the government wanted and then they didn't want to work with us anymore. They got tired of us Bininj [Aboriginal people]. They weren't interested in us anymore. That was after Ian Munro time. BAC used to make roads for us and so on, but the government policies changed, BAC's policies changed and they didn't want to support us anymore. (Bulanj Nakardbam, February 2015 quoted in Altman 2015)

19 Bawinanga management had initially resisted my recommendation that a narrative annual report be produced, but subsequently Ian Munro (pers. comm. 31 July 2015) informed me that he estimated that a $\$ 10,000$ investment in the report annually probably generated $\$ 250,000$ per annum for the corporation in additional grant support.

20 See register.oric.gov.au/document.aspx?concernID=100029, accessed 3 July 2015. 
Now that CDEP has been abolished, it is useful to reflect on what this program was and did, how this abolition was justified, why expert local knowledge about the local labour market was ignored, what has been lost following the reform process and how might any loss be recovered? While Bawinanga provides just one case study, the wealth of historical information about it provides a sound basis for such reflections.

CDEP was a program with multiple objectives that was established in recognition of the reality that there are limited mainstream employment opportunities in remote Australia and an escalating problem of surplus labour. And so the program empowered communities participating in the scheme to find creative ways to generate activity, pay wages and engage in community and enterprise development. While CDEP was an institution of the self-determination era, it nevertheless became increasingly governmental. This transition was a consequence of the Australian Government delegating authority to Aboriginal organisations to decide on the methods for the payment of income in accord with the rules governing boards of these organisations set. This is one aspect of CDEP that stands out most today: while it was always an Indigenous-specific program and never welfare, the cost of the program was largely offset by welfare - the notional entitlements of participants to income support and the cost of its delivery that government has to bear in remote places.

In the case of Bawinanga, as this chapter shows, a great deal was achieved with CDEP in a number of areas. Initially, CDEP provided an appropriate form of income support to outstations and generated operational funds to allow better service delivery to over 30 outstations scattered over a large remote region. Then, as CDEP expanded, it allowed for enterprise development, expanded community services and the provision of employment and training opportunity for up to 600 participants. It is interesting in this regard that while CDEP has been criticised for allowing cost shifting from government onto a government-funded community organisation in a situation of labour surplus, such service delivery work was an important avenue for job creation in aged care support, night patrol and other services more usually associated with government. 
While all these different elements of CDEP developed incrementally over time, they operated symbiotically and constituted a virtuous cycle: CDEP labour could be deployed in community services provision and enterprise development and the financial surpluses generatedespecially when supported by complementary government grantscould be rolled back into job creation and associated income generation for individuals, households and the community. While Bawinanga's initial focus was on outstations, its expanded role as a regional organisation from 1989 saw its activities increasingly focused on the township of Maningrida where a growing proportion of its membership lived.

Using the lenses of formal performance evaluation and outcomes monitoring, it is difficult to fault Bawinanga as a CDEP organisation; indeed it was often lauded, including as a case study of governance success in a report, The top 500 Aboriginal and Torres Strait Islander corporations 2009-2010 (Office of the Registrar of Indigenous Corporations 2011: 9-10). With access to CDEP, Bawinanga became one of the largest and most robust Indigenous corporations in Australia, regularly ranking between second- and fourth-largest of several thousand in the first decade of the 21 st century.

While Bawinanga was a successful CDEP performer there were many other CDEP organisations that, in their own ways, achieved a great deal in very difficult circumstances. So how was the Australian Government able to mount a plausible case to reform this program to extinction?

It is worth recalling here a growing policy debate about and mounting discursive assault on CDEP that began some 20 years ago and escalated rapidly during the post-ATSIC era. In rapid succession, a review of the scheme by the Human Rights and Equal Opportunity Commission (1997) questioned whether it was delivering income support equitably, the Spicer Review (1997) challenged the efficacy of the scheme as an employment program, and a combination of Pearson (2000) and McClure (2000) questioned whether CDEP jobs were 'real' and how CDEP fitted into a 'mutual obligation' framework (Altman 2001). Sanders (2001) captured these emerging challenges by noting that CDEP was being reshaped in two directions at once: a greater 
focus on integration into the social security system for unemployed participants and a greater focus on mainstream employment for those seeking exit.

Rowse (2001a) noted astutely at that time that CDEP was practically strong but ideologically weak as it struggled to escape the government's negative representations of CDEP. Rowse believed that while CDEP was not getting all the recognition it deserved for all the things that it did, it was still going to be hard to get rid of. But the government did get rid of CDEP, the scheme being eliminated by a pincer combination of the new managerialism and an increasingly shrill narrative of negativity.

In her recently completed doctoral research, Juliet Checketts (2016) analysed the federal parliamentary record to show how four dominant discourses combined to create what Foucault termed 'A Regime of Truth' (Foucault 1980) in the Australian Indigenous policy cycle. Regimes of Truth are established forms of knowledge and speech acts that frame social problems in a particular way, imagine government-directed interventions and envision the characteristics of desirable citizens that such interventions will create. The discourses Checketts identified were: highlighting of past failure, focused especially on ATSIC and the self-determination era; an ongoing concern with statistical gaps; a focus on Aboriginal culture and community as a barrier to progress; and a proposed solution to deliver the 'good life' enjoyed by mainstream settler Australians based on altering Indigenous subjectivities in remote Australia to embrace dominant norms and values. I cannot go into detail here analysing policy statements that encapsulated this emerging Regime of Truth, but two that stand out for me were Amanda Vanstone's (2007) speech on 'conspicuous compassion'21 and Malcolm Brough's (2006) speech, 'Blueprint for action on Indigenous affairs'. Both were powerful narratives of sameness and individualism for Indigenous Australia dressed up as tolerance of community and cultural difference.

These broader shifts in the Indigenous policy cycle can be transposed onto what was supposedly happening with CDEP according to the dominant narrative: the program was ATSIC's largest, and so could

21 A term probably borrowed, without acknowledgement, from West's book Conspicuous Compassion: Why Sometimes it Really is Cruel to be Kind (2004). 
be linked to ATSIC's perceived failure; redefined as an employment program it could be held responsible in part for the government's inability to close the employment gap; ${ }^{22} \mathrm{CDEP}$ 's emphasis on flexibility, including to accommodate cultural prerogatives like ceremony, explained participants' lack of regimentation for mainstream work; and the only way to enjoy the good life was through mainstream so-called 'real' jobs.

This Regime of Truth became so 'naturalised' that it was difficult to challenge. Have the supposed millions, sometimes billions, spent delivered acceptable outcomes? Can rich Australia tolerate such employment gaps? Can Australia really condone custom that precludes regular work or work readiness? And surely everyone deserves a decent livelihood based on full-time employment? Indigenous Australians should not be expected to tolerate second-class forms of employment and second-rate employment and training services. This is despite capitalism's core structural problem of low employment creation around its peripheries, especially where there are no markets to create.

In its attempts to counter such a dominant narrative in 'the CDEP Wars' and through evidence of its performance to parliamentary inquiries, Bawinanga, powerful as it was in regional political terms, could not counter this groundswell of critique. It was fighting a local battle for CDEP based on evidence of performance in a national ideological war in Australian Indigenous affairs in which inevitably Bawinanga ended up as the loser - its community-based developmental approach, even if successful, was out of broader policy fashion. Here was a classic case of social injustice, to invert Nancy Fraser's (2009) scales of justice framework to the negative: Bawinanga's efforts were poorly recognised, the organisation and its membership were poorly represented, and the redistribution of resources for Bawinanga was always inadequate to allow it to break its high dependence on the state and associated vulnerability.

22 Rowse (2001a: 232) highlighted the dominant message from Peter Shergold, then head of the powerful Employment portfolio, at the Indigenous Welfare Economy and CDEP conference: that CDEP is all about employment and as an employment program it is failing. But Shergold, of course, failed to specify what would work better. 
In their submission to the parliamentary inquiry into Indigenous employment, Munro and Manners (2005) ask: What would a postCDEP environment look like for Bawinanga, its members and the Maningrida region?

First and foremost, they predicted a depopulation of outstations in the region because of lack of services support and a means to make a livelihood through CDEP and top up in cash from art, or in-kind from hunting and fishing. This prediction has come to fruition and is reflected in the statement above from Bulanj Nakardbam in an interview conducted in February 2015 in Maningrida (Altman 2015).

Next, they noted the importance of CDEP for regional natural resource management and the associated maintenance of Indigenous environmental knowledge. ${ }^{23}$

They then suggested that without CDEP individuals will be deprived of self-esteem, there will be heightened social dysfunction and associated health and incarceration costs for the state. They also predicted that the service delivery undertaken by Bawinanga, including in delivering income support entitlements, will fall on a less locally attuned state apparatus. This prediction has seen rapid escalation of breaching by Centrelink for non-compliance since the establishment of RJCP (recently renamed CDP).

And finally they predicted that the quest for 'real jobs' will see Aboriginal people move from CDEP work to welfare while nonIndigenous people from outside Maningrida will increasingly take on the real or salaried jobs owing to superior qualifications and higher labour productivity in a market sense. Analysis comparing 2006 and 2011 census information supports this view, with non-Indigenous local employment increasing significantly during this period. ${ }^{24}$

The rhetoric of recent Australian governments highlights the need to empower communities and close the gap and to focus the policy effort of its Indigenous Advancement Strategy on remote Australia.

23 Some of this loss might have been offset by the introduction of the Working on Country program in 2007, but such 'working on country' without people living on country will prove far less effective.

24 From 126 in 2006 to 178 in 2011, according to ABS community profiles with median individual incomes for non-Indigenous employees nearly five times higher than for Indigenous people. Since 2011 this level of outsider employment has increased further. 
But the Bawinanga case indicates quite clearly that these goals are only considered if on the government's terms, irrespective of organisational performance. To some extent, Bawinanga has become too preoccupied with its own corporate survival and now risks meeting none of its objectives properly - in the support of outstations, in delivering community services, in developing viable small businesses and in providing locally realistic and flexible forms of training and work. When it successfully tendered for the role of regional RJCP provider as a financial survival strategy in 2013, the organisation acquiesced in large measure to the government's vision for the region rather than its own.

Bawinanga's symbiotic engagement with CDEP, carefully configured and nurtured over many years, is now broken. Without CDEP there is little incentive for individuals to work, as top up is not payable, and the organisation itself faces constrained incentive to perform as operating surpluses need to be earmarked for debt repayment rather than innovative enterprise development. Having created this terrible mess, the Australian Government is now belatedly looking for a semantic solution - renaming RJCP as the Community Development Programme - to a deeply entrenched structural problem that CDEP once empowered Bawinanga to address in a relatively successful way.

In the essay 'What is Living and What is Dead', historian Tony Judt (2015: 336) reminds us, as does Tim Rowse (2001a: 233), that social democrats need to speak more assertively of past gains. According to Judt it is those from the Right, those that espouse neoliberal ideology, that look to destroy and innovate in the name of a universal project of sameness. But this grand project would certainly not accord with the aspirations of many remote-living Indigenous Australians. CDEP may have been far from perfect and its contributions to ameliorate development challenges partial. But, as Judt (2015: 336) suggests in a broader global context that has strong resonances with the Maningrida local, 'Imperfect improvements upon unsatisfactory circumstances are the best that we can hope for, and probably all we should seek'.

Unfortunately, circumstances today are more unsatisfactory than at any time during the era of CDEP administered by Bawinanga: people are moving from outstations, more are engaging in unproductive make work under CDP just earning the Newstart Allowances, and livelihoods are more precarious (Altman 2015). 
This chapter does not seek to provide an uncritical idealisation of the past under CDEP, even though there is little question in the Maningrida region that those participating in the scheme were better off than those on welfare, with the overall numbers of adults pretty evenly divided between the two categories of CDEP participation and welfare. It is difficult to argue that a return to some halcyon period when CDEP was operating strongly is 'the' development solution; the regional challenges are too great to be solved by one organisation and one program. But there is no doubt that with CDEP Bawinanga delivered a great deal to its members and to the region, something that one would hope to see replicated in the future.

It is for this reason that in my view the current 'Regimes of Truth' about CDEP need to be sternly challenged with a counter-narrative built around three facts.

First, CDEP was never welfare; it was an innovative program with a notional financial nexus to welfare entitlements that empowered Aboriginal organisations like Bawinanga.

Second, Bawinanga did some very productive things with CDEP resources that are proving extremely difficult to emulate today without CDEP.

And finally, whatever its shortcomings, CDEP as administered by Bawinanga was better than welfare, for individuals, the Maningrida community and its network of outstations, for the region, and ultimately for the Australian nation.

\section{Acknowledgements and a disclosure of interest}

Over many years since 1979, too many people to name individually have assisted me with research in the Maningrida region. I would like to specifically thank Dan Gillespie and Ian Munro for checking the factual basis of my recollections and providing commentary on this chapter; and Kirrily Jordan, Melinda Hinkson, Bree Blakeman and especially Thomas Michel, as well as anonymous reviewers, for expert critical commentary on an earlier version. 
When I write about Bawinanga Aboriginal Corporation it is proper that I disclose that I am a foundation director of Karrkad-Kanjdji Ltd, a company that has been established to assist the Djelk Rangers (and adjoining Warddeken Rangers) in their land and resource management activities in Western Arnhem Land. Directors of Karrkad-Kanjdji Ltd are trustees for the Karrkad-Kanjdji Trust, established with deductible gift recipient status to financially assist the Djelk Rangers. The Djelk Rangers are in turn one of the most significant business units of BAC. The views that are expressed in this chapter are mine as an academic researcher and do not reflect the views of anyone else including other directors of Karrkad-Kanjdji Ltd.

\section{References}

ACIL Tasman (2007). Business opportunities in the Maningrida area: scoping report on business opportunities, infrastructure and capacity, Prepared for Bawinanga Aboriginal Corporation, ACIL Tasman Pty Ltd, Perth.

Altman JC (2001). 'Mutual obligation', the CDEP scheme, and development: prospects in remote Australia. In Morphy F \& Sanders $\mathrm{W}$ (eds), The Indigenous welfare economy and the CDEP scheme, CAEPR Research Monograph No. 20, ANU E Press, Canberra.

Altman JC (2005). The governance of outstations in the Maningrida region, north-central Arnhem Land, and the challenges posed by the new arrangements, ICGP Occasional Paper No. 11, Indigenous Community Governance project, CAEPR, The Australian National University, Canberra.

Altman JC (2008). Different governance for difference: the Bawinanga Aboriginal Corporation, In Hunt J, Smith DE, Garling S \& Sanders W (eds), Contested governance: culture, power and institutions in Indigenous Australia, ANU E Press, Canberra, 177-203.

Altman JC (2014). Indigenous policy: Canberra consensus on a neoliberal project of improvement. In Miller C \& Orchard L (eds), Australian public policy: progressive ideas in the neoliberal ascendancy, Policy Press, Bristol, 117-134. 
Altman JC (2015). Living the good life in precarious times. Inside Story, 2 June 2015, insidestory.org.au/living-the-good-life-in-precarioustimes.

Altman JC \& Johnson V (2000). CDEP in town and country Arnhem Land: Bawinanga Aboriginal Corporation, CAEPR Discussion Paper No. 209, CAEPR, The Australian National University, Canberra.

Anderson P (2010). Bawinanga Aboriginal Corporation achievements review in order to identify practices which might productively be pursued elsewhere in remote areas of the Northern Territory, Peter Anderson Consulting Pty Ltd, Darwin.

Australian Government (1987). The Aboriginal Employment Development policy, Policy Paper No. 3, Community-based Employment, Enterprise and Development Strategies, Australian Government Publishing Service, Canberra.

Blanchard A (chairman) (1987). Return to Country: the Aboriginal Homelands movement in Australia, Australian Government Publishing Service, Canberra.

Boxall P (2012). Reflections of an 'unabashed rationalist.' In Wanna J, Vincent S \& Podger A (eds), With the benefit of hindsight: valedictory reflections from departmental secretaries, 2004-2011, ANU E Press, Canberra.

Brough M (2006). Blueprint for action in Indigenous affairs, Speech delivered at the National Institute of Governance, University of Canberra, Canberra, 6 December 2006, www.formerministers.dss. gov.au/2917/blueprint-for-action-in-indigenous-affairs/.

Checketts JC (2016). The pulse of policy: mapping movement in the Australian Indigenous policy world, unpublished $\mathrm{PhD}$ thesis, The Australian National University, Canberra.

Fogarty B \& Paterson M (2007). Constructive engagement: impacts, limitations and possibilities during a national emergency intervention, Report for BAC, PIA Consultants, August 2007, www.aph.gov.au/Parliamentary_Business/Committees/Senate/ Legal_and_Constitutional_Affairs/Completed_inquiries/2004-07/ nt_emergency/submissions/sublist. 
Foucault M (1980). Truth and power, Power/knowledge: selected interviews and other writings 1972-1977, C Gordon (ed.), Pantheon Books, New York.

Fraser $\mathrm{N}$ (2009). Scales of justice: reimagining political space in a globalizing world, Columbia University Press, New York.

HRSCATSIA (House of Representatives Standing Committee on Aboriginal and Torres Strait Islander Affairs) (2007). Indigenous Australians at work: successful initiatives in Indigenous employment. Commonwealth of Australia, Canberra.

Human Rights and Equal Opportunity Commission (1997). The CDEP scheme and racial discrimination: a report by the Race Discrimination Commissioner, Commonwealth of Australia, Canberra.

Johnson V (2000). Bawinanga Aboriginal Corporation annual report 1999/2000, Bawinanga Aboriginal Corporation, Maningrida.

Johnson V (2004). Bawinanga Aboriginal Corporation annual report 2003/2004, Bawinanga Aboriginal Corporation, Maningrida.

Judt $\mathrm{T}$ (2015). When the facts change: essays 1995-2010, J Homans (ed.), Penguin Press, New York.

Kohen A (2007). Maningrida Arts \& Culture, annual report, 2006-2007, Maningrida Arts and Culture, Maningrida.

Kohen A \& Sommers C (2008). Maningrida Arts \& Culture, annual report, 2007-2008, Maningrida Arts and Culture, Maningrida.

Kowal E (2012). Responsibility, Noel Pearson and Indigenous disadvantage in Australia. In Hage G \& Eckersley R (eds), Responsibility, Melbourne University Press, Melbourne.

Manners R (2001). Catering for mobility and diversity: Bawinanga Aboriginal Corporation CDEP, Northern Territory. In Morphy F, \& Sanders, W (eds), The Indigenous welfare economy and the CDEP scheme, ANU E Press, Canberra.

Manners W (2006). Bawinanga Aboriginal Corporation annual report 2005/2006, Bawinanga Aboriginal Corporation, Maningrida. 
Manners W (2007). Bawinanga Aboriginal Corporation annual report 2006/2007, Bawinanga Aboriginal Corporation, Maningrida.

Manners W (2009). Bawinanga Aboriginal Corporation annual report 2008/2009, Bawinanga Aboriginal Corporation, Maningrida.

Martin D (2001). Community development in the context of welfare dependence. In Morphy F \& Sanders W (eds), The Indigenous welfare economy and the CDEP scheme, ANU E Press, Canberra.

May K, Ansell S \& Koenig J. (2010). Djelk Rangers annual report 2009/2010, Djelk Rangers, Bawinanga Aboriginal Corporation, Maningrida.

McAuliffe C (2005). Bawinanga Aboriginal Corporation annual report 2004/2005, Bawinanga Aboriginal Corporation, Maningrida.

McLure P (chair) (2000). Participation support for a more equitable society: final report of the Reference Group on Welfare Reform, July 2000, Department of Families and Community Services, Canberra.

Michel T \& Taylor A (2014). Death by a thousand grants? The challenge of grants funding reliance for local government councils in the Northern Territory of Australia. Local Government Studies, 38 (4): 485-500.

Miller M (chairman) (1985). Report of the Committee of Review of Aboriginal Employment and Training Programs, Australian Government Publishing Service, Canberra.

Morphy F \& Sanders W (eds) (2001). The Indigenous welfare economy and the CDEP scheme, CAEPR Research Monograph No. 20, ANU E Press, Canberra.

Munro I (2006). Correspondence to the Commonwealth Ombudsman, dated July 82006.

Munro I (2010). Organisational review of Maningrida Arts and Culture, June 2010, Ian Munro Consulting. 
Munro I \& Manners R (2005). Submission (no. 20) to the House of Representatives Standing Committee on Aboriginal and Torres Strait Islander Affairs Inquiry Indigenous Australians at Work on behalf of the Bawinanga Aboriginal Corporation, available at www.aph.gov.au/parliamentary_Business/Committees/House_of_ Representatives_Committees?url=atsia/indigenousemployment/ subs.htm.

Office of the Registrar of Indigenous Corporations (2011). The top 500 Aboriginal and Torres Strait Islander corporations 2009-2010, Office of the Registrar of Indigenous Corporations, Canberra.

Pascal H \& Ansell S (2009). Djelk Rangers annual report, 2008-2009, Bawinanga Aboriginal Corporation, Maningrida.

Pearson N (2000). Our right to take responsibility, Noel Pearson and Associates, Cairns.

Rowse T (2001a). The political dimensions of community development. In Morphy F \& Sanders W (eds), The Indigenous welfare economy and the CDEP scheme, CAEPR Research Monograph No. 20, ANU E Press, Canberra.

Rowse T (2001b). Postscript. In Morphy F \& Sanders W (eds), The Indigenous welfare economy and the CDEP scheme, CAEPR Research Monograph No. 20, ANU E Press, Canberra.

Rowse T (2002). Indigenous futures: choice and development for Aboriginal and Islander Australia, UNSW Press, Sydney.

Sanders W (2001). Adjusting balances: reshaping the CDEP scheme after 20 good years. In Morphy F \& Sanders W (eds), The Indigenous welfare economy and the CDEP scheme, CAEPR Research Monograph No. 20, ANU E Press, Canberra.

Sanders W (2004). Indigenous centres in the policy margins: the CDEP scheme over 30 years, CAEPR Topical Issue 12/2004, caepr.anu.edu.au/sites/default/files/Publications/topical/ CDEP\%20Sanders2004.pdf.

Sanders W (2012). Coombs' bastard child: the troubled life of CDEP. Australian Journal of Public Administration, 71 (4): 371-91. 
Sommers C (2010). Bawinanga Aboriginal Corporation annual report 2009/2010, Bawinanga Aboriginal Corporation, Maningrida.

Sommers C (2011). Bawinanga Aboriginal Corporation annual report 2010/2011, Bawinanga Aboriginal Corporation, Maningrida.

Spicer I (1997). Independent review of the Community Development Employment Projects (CDEP) scheme, Aboriginal and Torres Strait Islander Commission, Canberra.

Sullivan P (2011). Belonging together: dealing with the politics of disenchantment in Australian Indigenous policy, Aboriginal Studies Press, Canberra.

Tallegalla Consultants Pty Ltd (2003). Bawinanga Aboriginal Corporation, strategic plan 2004-2006, Unpublished report, Tallegalla Consultants Pty Ltd, Noosaville, Queensland.

Tallegalla Consultants Pty Ltd (2009). Bawinanga Aboriginal Corporation Maningrida NT, Ye Ya mud brick factory-feasibility study report, Tallegalla Consultants Pty Ltd, Brisbane.

Vanstone A (2007). Beyond conspicuous compassion: Indigenous Australians deserve more than good intentions. In Wanna J (ed.), A passion for policy: essays in public sector reform, ANU E Press, Canberra.

West P (2004). Conspicuous compassion: why sometimes it really is cruel to be kind, Civitas: Institute for the Study of Civil Society, London. 
This text is taken from Better Than Welfare?: Work and livelihoods for Indigenous Australians after CDEP, edited Kirrily Jordan, published 2016 by ANU Press, The Australian National University, Canberra, Australia. 